\title{
Honouring Dr Alease Brown
}

This volume is dedicated to honouring the memory of Dr Alease Brown who was the initial lead editor of this special issue before her untimely passing. The impact of her sudden demise and the yawning gap that she left among the members of the Circle is aptly captured in the eulogy prepared by Professor Musa Dube, the current continental coordinator of the Circle, in the following words:

On the morning of $12^{\text {th }}$ March 2020, we learnt, with great shock and sorrow that Dr Alease Brown had passed on. A cloud of sadness, tears, broken hearts and silence descended upon members of the Circle of Concerned African Women Theologians and all who knew her, as we tried to come to terms with her untimely passing. Dr Alease Brown was a Postdoctoral Fellow at the Desmond Tutu Centre for Religion and Social Justice at the University of the Western Cape, having completed her PhD in Systematic Theology at Stellenbosch University in Cape Town in 2019.

Dr Brown attended the $5^{\text {th }}$ Pan African Circle of Concerned African Women Theologians' Conference and $30^{\text {th }}$ Anniversary celebrations from July 1-5, 2019, which were held at the University of Botswana. She presented a paper entitled, "The Discourse of Drought: Ongoing Gendered Inequality in Water Access in Cape Town, and Implications for Public Theology." During the gathering, Dr Brown was among the young scholars who were conferred the "Rising Star of the Circle Award" by Prof Mercy Amba Oduyoye, the founder of the Circle. The award commissioned younger scholars to carry on the mandate of the Circle for the coming decades. Dr Alease Brown was further elected the National Coordinator of the Circle chapter of the Republic of South Africa, charged with driving research and publication among Circle members in South Africa. She also assumed the role of a guest editor of a special issue of the African Journal for Gender and Religion on the theme of Sacred Earth, 
which consisted of papers selected among the eighty presentations given at the $5^{\text {th }}$ Pan African Circle Conference. Simultaneously, Dr Brown wrote and circulated a call for papers in honour of Prof. Katie Geneva Cannon, thereby encouraging Sisters of the Circle to engage and connect with the work of a famed diaspora theologian and ethicist. At the time of her passing, Dr Brown had made significant progress towards coordinating these editorial projects, and we believe her peers will ensure their completion. ${ }^{1}$

The completion of this volume is the fulfilment of the heartfelt wish presented in the above eulogy. As members of the Circle grappled with the reality of the passing of our sister Alease, it was unanimously agreed that dedicating this volume to honour her memory would be one of the ways of celebrating her life and work. As a result, the co-editors of the volume, Sophie Chirongoma and Sue Rakoczy were given the mandate to complete the noble task which Alease had started so as to ensure that her hard work comes to fruition. Fitting into Alease's gigantic shoes was no mean feat. It was a real labour of love. Her endearing and 'infectious' smile, her resilience and tenacity continued to spur us on whenever the going got really tough. This volume therefore celebrates the life of Alease, a daughter of the soil. Compiling this piece is a really bitter sweet pill; as we honour our sister, our hearts are heavy with grief. It is an emotionally packed undertaking. The void she left is inexpressible. Alease would have been the one to compile this piece but she has since passed on the torch to us. Following her bidding, it is with a sense of accomplishment that we present the work she left for us to complete.

Alease was full of life; she was passionate about the plight of all those who are pushed to the peripheries of society on the basis of race, social class or gender. Her life and work as an academic activist and a religious leader

Musa Dube, "Unpublished Eulogy for Dr Alease Brown," circulated via email to members of the Circle on the $15^{\text {th }}$ of March, 2020. 
are succinctly summarized below in the eulogy prepared by the "Daughters of the African Atlantic".

Alease Brown, Ph.D. was a theologian, social justice advocate, and global religious leader. She was a postdoctoral fellow at the University of the Western Cape (Cape Town, SA) and worked with the Desmond Tutu Centre for Religion and Social Justice. Dr. Brown was particularly interested in the topic of human dignity as it is realized by, or impeded in, the lives of Black women of the African diaspora. Her research probed race and gender justice, protest, resistance, discourses of (non)violence through the lens of critical theory, Africana, gender, and postcolonial (decolonial) studies, biblical studies, and early church history. She completed her PhD in Systematic Theology at Stellenbosch University (Cape Town, SA). Before her passing, Dr. Brown was the "on the ground" South Africa liaison for the Daughters and served on the 2020 Daughters Consultation Committee. Dr. Brown held a deep love for connecting people, preaching the gospel, drawing out new theological meaning from familiar passages, and sharing light with the world. In her words, "she was born for this! ${ }^{2}$

As evidently captured in the above eulogy, Alease was born to serve; she was committed to transforming the world into a better place for all. To achieve this goal, Alease travelled around the world and she practiced what she preached. The following excerpt from the eulogy prepared by Professor Musa Dube says it all:

Dr Alease Brown, originally from Long Island, New York State, was a diasporic sister who came to dwell amongst us. She crossed many cultural, economic, racial, class, gender and political boundaries to

2 Daughters of the African Atlantic Fund, "The Daughters of the African Atlantic Remembers Dr. Alease Brown," https://www.africanatlanticdaughters.com/2020/07/21/the-daughtersremembers-dr-alease-brown/ (Accessed 30 November, 2020) 
be rejoined with her sisters and brothers in the Mother Continent of Africa, thereby bridging many broken boundaries... We were looking forward to the gifts that Dr Alease Brown would confer upon us by her coming to learn, live, lead and work with us in the Mother Continent. $^{3}$

In celebration of the dedication that Alease had towards strengthening ties between the brothers and sisters in the North and the South, the contributors to this special issue interact with Alease's work around the theme of the intertwinements between the sacredness of the Earth, climate change and gender justice issues.

\section{References}

Daughters of the African Atlantic Fund, "The Daughters of the African Atlantic Remembers Dr. Alease Brown,"

https://www.africanatlanticdaughters.com/2020/07/21/the-daughtersremembers-dr-alease-brown/ (Accessed 30 November, 2020)

Dube, Musa. Unpublished Call for Papers for the Circle of Concerned African Women Theologian $5^{\text {th }}$ Pan-African Conference on the theme "Mother Earth and Mother Africa in

Theological/Religious/Cultural/Philosophical Imagination," circulated via email on the $11^{\text {th }}$ of December, 2018.

3 Musa Dube, "Unpublished Eulogy for Dr Alease Brown". 